\title{
PERUBAHAN SIFAT KIMIA TANAH SETELAH APLIKASI TANDAN KOSONG KELAPA SAWIT PADA DUA KELAS TEKSTUR TANAH
}

\section{Changes in Soil Chemical Properties after Application of Oil Palm Empty Fruit Bunch on Two Soil Texture Classes}

\author{
Putri Winda Asih, Sri Rahayu Utami, Syahrul Kurniawan* \\ Jurusan Tanah, Fakultas Pertanian, Universitas Brawijaya, Malang 65145 \\ *penulis korespondensi: syahrul.fp@ub.ac.id
}

\begin{abstract}
The increase production of oil palm plantation is followed by the residue from processing palm oil mill effluent (POME) and oil palm empty fruit bunches (EFB). The POME is widely applied in oil palm plantation, whereas EFB is limited used. This study aimed to determine the effect of EFB application on soil chemical properties in Ultisol. This study was conducted in the Soil Chemical and Biological Laboratories, Agriculture Faculty, Brawijaya University Malang. Soil samples were collected from Batanghari and Sarolangun regencies, Jambi Province. This study was designed using randomized complete design with 6 treatments, including clay loam Ultisol (CLU) + EFB (T1B1); $\mathrm{CLU}+$ palm oil fibre (T1B2); CLU + EFB + fibre (T1B3); sandy loam Ultisol (SLU) + EFB (T2B1); SLU + fibre (T2B2); SLU + EFB + fibre (T2B3), and 3 replicates. The results showed that application oil palm residues (e.g EFB and fibre) increased soil organic C, available $\mathrm{K}$, total $\mathrm{N}$, and CEC on clay loam Ultisol with the highest increase was observed at the T1B3 (CLU + EFB + fibre) for 12 weeks incubation. This study summarized that oil palm residues can potentially be used as organic fertilizer in oil palm plantation.
\end{abstract}

Keywords : clay loam, oil palm empty fruit bunch, organic material, sandy loam, Ultisol

\section{Pendahuluan}

Kelapa sawit (Elaeis guineensis Jacq) merupakan tanaman primadona sekaligus andalan komoditas perkebunan di Jambi. Pada tahun 2016, luas areal perkebunan kelapa sawit di Jambi mencapai 736.095 ha dengan produksi sebesar 1.910.028 ton CPO (Crude Palm Oi) (Direktorat Jenderal Perkebunan, 2016). Pada umumnya setiap perkebunan kelapa sawit terutama perkebunan besar dilengkapi dengan pabrik kelapa sawit (PKS) untuk mengolah tandan buah segar (TBS) menjadi CPO. Setiap PKS dengan kapasitas $60 \mathrm{t} \mathrm{jam}^{-1}$ dapat mengolah TBS hingga $1000 \mathrm{t} \mathrm{ha}^{-1}$ (Eliarti, 2013). Pengolahan TBS menghasilkan limbah antara lain 23\% tandan kosong; 6,5\% cangkang dan 13\% serat (Departemen Pertanian, 2006).
Untuk mengurangi pencemaran lingkungan yang berasal dari residu pengolahan kelapa sawit, perlu dilakukan penanganan limbah pabrik kelapa sawit.

Salah satu cara yang dapat dilakukan adalah dengan memanfaatkan limbah padat kelapa sawit sebagai pupuk organik. Tandan kosong merupakan residu kelapa sawit yang berpotensi sebagai pupuk orgnik karena mempunyai kandungan hara yang cukup tinggi, yakni memiliki kandungan unsur nitrogen $1,5 \%$, Fosfat $0,5 \%$, kalium $7,3 \%$ dan magnesium 0,9\% (Manambangtua dan Barri, 2016). Tandan kosong dapat digunakan sebagai pupuk organik bagi pertanaman kelapa sawit secara langsung maupun tidak langsung. Pemanfaatan secara langsung yaitu dengan menyebarkan tandan kosong pada daerah 


\section{Jurnal Tanah dan Sumberdaya Lahan Vol 6 No 2 : 1313-1323, 2019 \\ e-ISSN:2549-9793, doi: 10.21776/ub.jts1.2019.006.2.12}

piringan, sedangkan secara tidak langsung harus melalui proses pengomposan terlebih dahulu.

Di Indonesia, perkebunan kelapa sawit umumnya banyak tersebar di wilayah Sumatra dan Kalimantan, dengan kondisi tanah yang kurang subur karena banyak didominasi oleh jenis tanah Ultisol. Ultisol merupakan tanah mineral dengan penyebaran cukup luas di Indonesia yakni mencapai 45.794 .000 ha atau sekitar 25\% dari total luas daratan Indonesia (Prasetyo dan Suriadikarta, 2006). Permasalahan yang dihadapi pada lahan Ultisol adalah $\mathrm{pH}$ sangat masam dengan $\mathrm{pH}$ rata-rata $<$ 4,50; kandungan bahan organik rendah; kandungan basa-basa dan $\mathrm{P}$ rendah; kapasitas tukar kation (KTK) rendah serta kejenuhan $\mathrm{Al}$ tinggi (Prasetyo dan Suriadikarta, 2006). Salah satu upaya untuk memperbaiki tingkat kesuburan Ultisol adalah melalui pemberian bahan organik, salah satunya adalah memanfaatkan residu kelapa sawit seperti tandang kosong. Tandan kosong kelapa sawit dapat digunakan sebagai bahan pupuk organik untuk memperbaiki kesuburan tanah Ultisol, karena tersedia melimpah terutama di daerah yang mempunyai perkebunan kelapa sawit yang cukup luas.

Penelitian ini bertujuan untuk mempelajari pengaruh penambahan tandan kosong kelapa sawit (TKKS) terhadap ketersediaan unsur hara $(\mathrm{N}, \mathrm{P}, \mathrm{K}, \mathrm{Ca}, \mathrm{Mg}$, dan $\mathrm{Na})$ dan sifat bio-kimia tanah $(\mathrm{pH}, \mathrm{C}$-organik, dan K'TK) di Ultisol.

\section{Bahan dan Metode}

Penelitian dilaksanakan di Laboratorium Kimia dan Biologi tanah, Jurusan Tanah Fakultas Pertanian Universitas Brawijaya Malang. Penelitian ini dilakukan dimulai bulan Desember 2017 - Mei 2018. Alat yang digunakan dalam penelitian ini adalah polybag $15 \times 20 \mathrm{~cm}$, timbangan digital, nampan, gunting, oven, alat tulis, kamera dan alat-alat laboratorium yang mendukung untuk masingmasing analisis unsur hara $(\mathrm{C}, \mathrm{N}, \mathrm{P}, \mathrm{K}, \mathrm{Ca}, \mathrm{Mg}$, $\mathrm{Na})$ dan sifat kimia tanah ( $\mathrm{pH}$ dan KTK). Bahan yang digunakan dalam penelitian ini meliputi tanah lapisan atas dari Ultisol, limbah kelapa sawit (tandan kosong kelapa sawit dan serabut), dan bahan-bahan kimia yang digunakan untuk analisis kimia tanah di laboratorium. Tanah yang digunakan dalam penelitian ini Ultisol yang berbeda teksturnya: lempung berliat dan lempung berpasir, yang diambil dari Desa Baru - Kabupaten Sarolangun dan Desa Sungkai - Kabupaten Batanghari, Propinsi Jambi. Sedangkan residu kelapa sawit diambil dari produk buangan perusahaan pengolahan kelapa sawit di Propinsi Jambi.

Penelitian ini menggunakan Rancangan Acak Lengkap (RAL) dengan 6 perlakuan dan 3 kali ulangan. Perlakuan penelitian meliputi: T1B1 = Ultisol lempung berliat + TKKS; T1B2 = Ultisol lempung berliat + serabut (fiber); $\mathrm{T} 1 \mathrm{~B} 3=$ Ultisol lempung berliat + TKKS + serabut (fiber); T2B1 = Ultisol lempung berpasir + TKKS; T2B2 = Ultisol lempung berpasir + serabut (fiber); T2B3 = Ultisol lempung berpasir + TKKS + serabut (fiber). Tanah yang sudah diambil dari Jambi dikering-udarakan selama 7 hari, kemudian dihaluskan hingga lolos ayakan $2 \mathrm{~mm}$. Sedangkan bahan organik (tandan kosong dan serabut) dikering-udarakan selama 3 hari kemudian dipotong-potong dengan ukuran \pm 2 $\mathrm{cm}$. Setelah dikering-udarakan, tanah dan bahan organik yang digunakan dalam penelitian, diukur kadar airnya.

Sebelum pencampuran bahan organik ke tanah, tanah yang sudah halus ditimbang $(\sim 400$ $\mathrm{kg}$ kering oven) kemudian dimasukkan ke dalam polibag dan dicampur dengan bahan organik sesuai perlakuan. Banyaknya bahan organik (tandan kosong dan serabut) yang ditambahkan per polibag setara dengan 10 ton $\mathrm{ha}^{-1}$. Tanah yang sudah bercampur dengan bahan organik ditambah air sesuai dengan kapasitas lapangan, kemudian dinkubasi dan diamati pada 4, 6, 8, 10 dan 12 minggu setelah aplikasi bahan organik.

Parameter yang diamati adalah sifat kimia tanah seperti $\mathrm{pH}, \mathrm{C}$-organik, N-total, P tersedia, K-dd, KTK, Ca-dd, Mg-dd, dan Nadd. Data yang diperoleh dianalisis menggunakan ANOVA (uji F), dilanjutkan dengan uji BNT (beda nyata terkecil) bila ditemukan perbedaan / pengaruh yang nyata pada taraf 5\%. Selain itu, dilakukan uji korelasi antar parameter pengamatan pada taraf 5\% untuk mengetahui hubungan antar parameter. 


\section{Hasil dan Pembahasan}

\section{Nilai $p H$ Tanah}

Nilai $\mathrm{pH}$ tanah sangat berpengaruh dalam penyediaan unsur hara di dalam tanah yang akan diserap oleh tanaman.Kemasaman tanah (pH tanah) setelah perlakuan beragam antara perlakuan satu dengan yang lainnya (Gambar 1). Secara umum diketahui bahwa nilai $\mathrm{pH}$ tanah berada di kisaran 4,03 - 4,53 (kriteria sangat masam). Kisaran $\mathrm{pH}$ tanah yang diperoleh dari penelitian ini sama dengan $\mathrm{pH}$ tanah hasil penelitian Allen et al. (2015) di lahan kelapa sawit di Jambi yang berada pada kisaran 4.4 - 4.6. Kurniawan et al. (2018) juga melaporkan bahwa $\mathrm{pH}$ tanah $\left(\mathrm{pH} \mathrm{H}_{2} \mathrm{O}\right)$ pada 3 lokasi di kebun kelapa sawit (piringan, di bawah tumpukan pelepah, dan antar pohon) berkisar antara 4,41 - 4,53. Hasil analisis ragam menunjukkan bahwa pemberian tandan kosong kelapa sawit pada Ultisol yang bertekstur lempung berpasir dan lempung berliat tidak berpengaruh nyata terhadap $\mathrm{pH}$ tanah. Hal ini diduga karena tanah Ultisol yang digunakan di dalam penelitian ini memiliki $\mathrm{pH}$ yang sangat masam sehingga pemberian bahan organik tidak cukup kuat untuk meningkatkan $\mathrm{pH}$ tanah. Untuk itu, aplikasi bahan organik yang berasal dari residu kelapa sawit (EFB dan serabut) perlu ditambah dengan kapur / dolomit guna meningkatkan $\mathrm{pH}$ tanah, sekaligus menambah basa-basa tersedia di dalam tanah. Bakar et al. (2011) melaporkan bahwa peningkatan $\mathrm{pH}$ tanah Ultisol sebanyak 2 unit terjadi setelah aplikasi tandan kosong kelapa sawit selama 10 tahun terus menerus.
4MSI

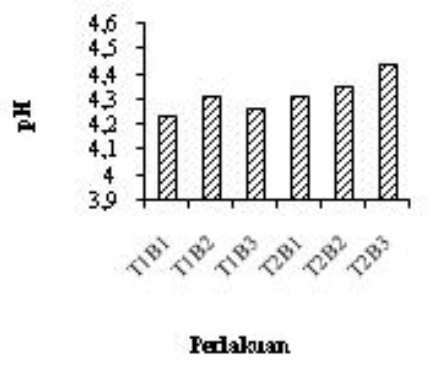

(a)

10 MSI

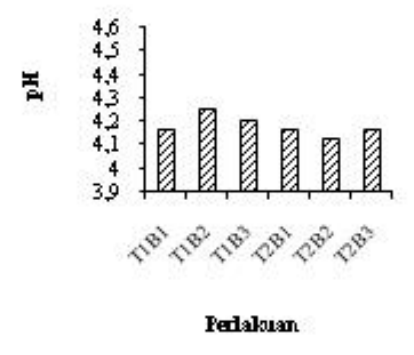

(d)

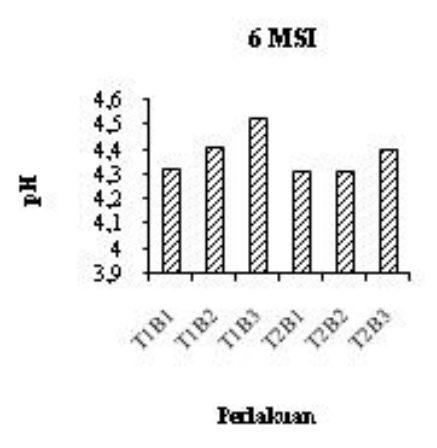

(b)

12 MSI

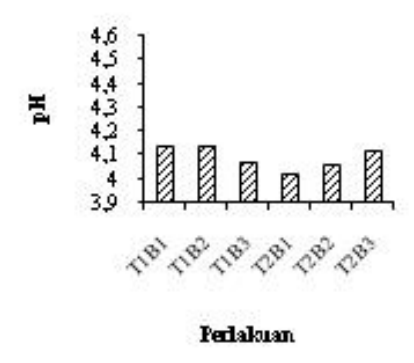

(e)

Gambar 1.Pengaruh perlakuan penambahan tandan kosong kelapa sawit terhadap $\mathrm{pH}$ tanah ( $\mathrm{pH}$

$\mathrm{H}_{2} \mathrm{O}$ ) pada waktu pengamatan 4 MSI (a), 6 MSI (b), 8 MSI (c), 10 MSI (d), dan 12 MSI (e).

Keterangan: T1 (Tekstur tanah lempung berliat); T2 (Tekstur tanah lempung berpasir); B1 (Tandan

Kosong Kelapa Sawit); B2 ( Serabut kelapa sawit); B3 (Tandan Kosong + Serabut kelapa sawit);

MSI (Minggu Setelah Inkubasi). 


\section{Kadar C-organik tanah}

Hasil analisa tanah dasar menunjukkan bahwa Ultisol memiliki kandungan C-organik tanah yang sangat rendah yaitu $0,54 \%$ (pada Ultisol tekstur lempung berliat) dan $0,4 \%$ (Ultisol tekstur lempung berpasir). Rendahnya kandungan C-organik pada tanah ini karena Ultisol merupakan tanah yang miskin unsur hara terutama kandungan bahan organik akibat pelapukan ataupun kehilangan (erosi dan pencucian). Prasetyo dan Suriadikarta (2006) melaporkan bahwa kandungan bahan organik tanah di Ultisol pada umumnya rendah karena proses dekomposisi yang berjalan cepat dan sebagian terbawa erosi. Hasil sidik ragam menunjukkan bahwa penambahan tandan kosong kelapa sawit berpengaruh nyata dalam meningkatkan C-organik tanah. Pemberian bahan organik berupa tandan kosong kelapa sawit (TKKS), serabut kelapa sawit dan kombinasi keduanya selama 12 minggu inkubasi meningkatkan kadar C-organik tanah bila dibandingkan dengan kondisi awal sebelum perlakuan (Gambar 2). Hal ini karena bahan organik tandan kosong kelapa sawit yang digunakan memiliki kandungan C-organik yang tinggi yaitu 38,66\% (Tandan kosong kelapa sawit), 40,69\% (serabut), dan 43,89\% (Tandan kosong + serabut kelapa sawit). Hasil penelitian ini sejalan dengan penelitian Darmosarkoro dan Winarna (2001) yang menyatakan bahwa kompos tandan kosong kelapa sawit yang dihasilkan oleh pabrik kelapa sawit merupakan sumber hara potensial yang berfungsi sebagai bahan pembenah tanah karena tingginya kandungan karbon yang terdapat dalam bahan organik. Gambar 2 menunjukkan bahwa Ultisol lempung berliat memiliki kadar C-organik yang lebih tinggi bila dibandingkan dengan Ultisol lempung berpasir.

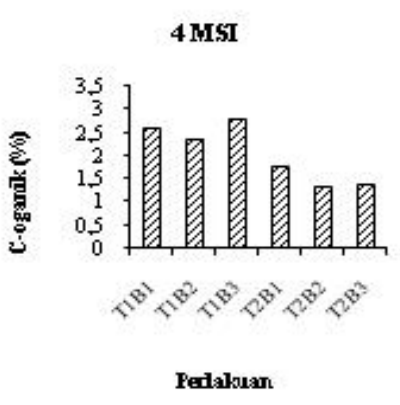

(a)

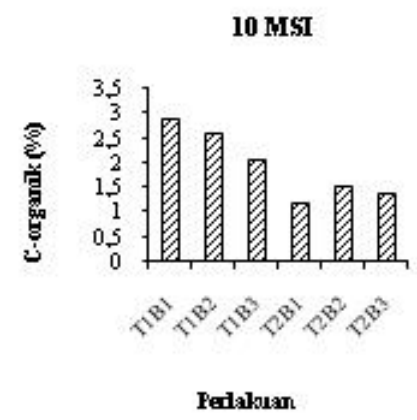

(d)

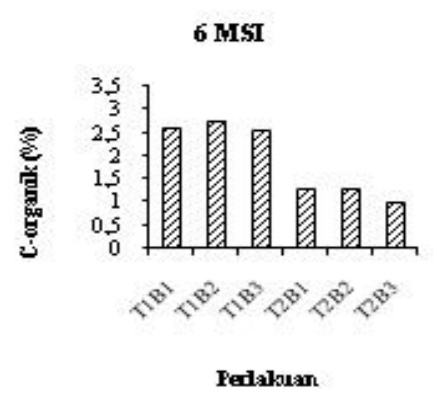

(b)

12 MSI

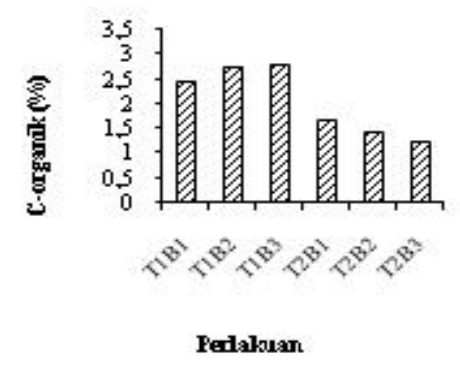

(e)

Gambar 2.Pengaruh perlakuan penambahan tandan kosong kelapa sawit terhadap C-organik tanah pada waktu pengamatan 4 MSI (a), 6 MSI (b), 8 MSI (c), 10 MSI (d), dan 12 MSI (e).

Keterangan: T1 (Tekstur tanah lempung berliat); T2 (Tekstur tanah lempung berpasir); B1 (Tandan Kosong Kelapa Sawit); B2 ( Serabut kelapa sawit); B3 (Tandan Kosong + Serabut kelapa sawit); MSI (Minggu Setelah Inkubasi). 
Hal ini selaras dengan hasil penelitian Allen et al. (2015 dan 2016) yang melaporkan bahwa kandungan $\mathrm{C}$ organik tanah pada lahan kelapa sawit di Jambi dengan jenis tanah Acrisol (Klasifikasi FAO) atau Ultisol (klasifikasi USDA) berliat cenderung lebih tinggi dibandingkan dengan Acrisol berlempung. Kandungan $\mathrm{C}$ organik tanah tertinggi terjadi pada waktu inkubasi 8 minggu, yakni pada perlakuan T1B1 (Ultisol lempung berliat + TKKS) sebesar 2,393\%. Hasil ini menunjukkan bahwa tandan kosong kelapa sawit memiliki potensi yang lebih besar di dalam meningkatkan bahan organik tanah. Secara umum, kandungan $\mathrm{C}$ organik tanah pada tanah Ultisol bertekstur lempung berliat lebih besar dibandingkan dengan lempung berpasir, diduga karena tekstur tanah lempung berliat memiliki kapasitas adsorpsi unsur-unsur hara lebih besar bila dibandingkan dengan tekstur tanah lempung berpasir.

\section{Kadar N-total tanah}

Hasil analisis pendahuluan menunjukkan bahwa tanah yang digunakan memiliki kandungan N-total tanah dengan kriteria sedang $(0,31 \%)$ dan sangat rendah $(0,09 \%)$, berturut-turut pada tekstur lempung berliat dan tekstur lempung berpasir. Berdasarkan hasil analisis sidik ragam didapatkan bahwa penambahan bahan organik berpengaruh nyata terhadap kadar N-total tanah. Gambar 3 menunjukkan bahwa Ultisol yang memiliki tekstur lempung berliat (T1B1, T1B2, dan T1B3) memiliki nilai $\mathrm{N}$-total lebih tinggi dibandingkan dengan tekstur lempung berpasir (T2B1, T2B2, dan T2B3).

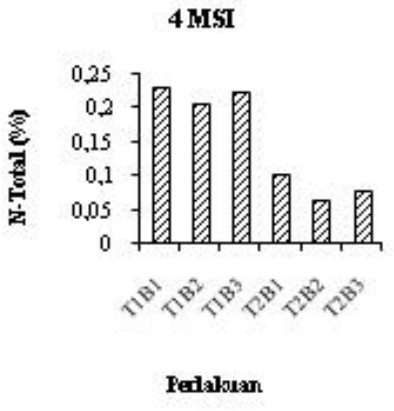

(a)

10 MSI

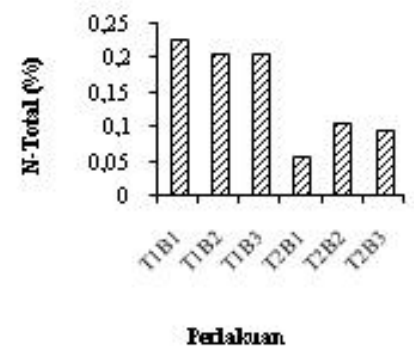

(d)

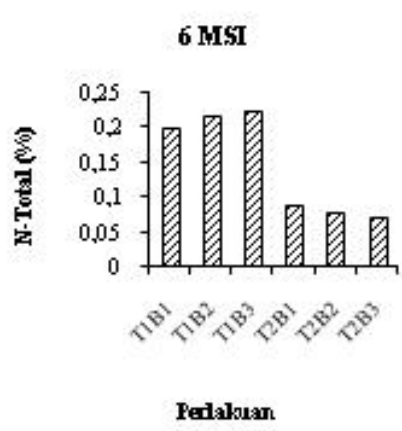

(b)

12 MSI

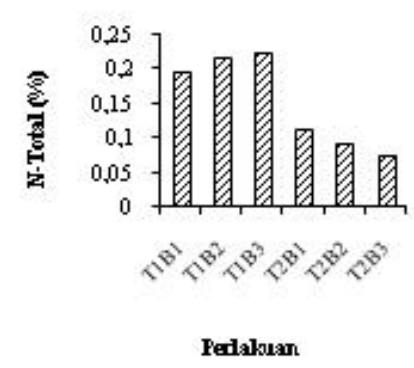

(e)

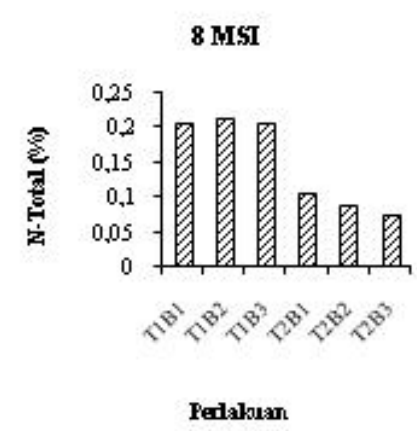

(c)

Gambar 3.Pengaruh perlakuan penambahan tandan kosong kelapa sawit terhadap N-total tanah pada waktu pengamatan 4 MSI (a), 6 MSI (b), 8 MSI (c), 10 MSI (d), dan 12 MSI (e).

Keterangan: T1 (Tekstur tanah lempung berliat); T2 (Tekstur tanah lempung berpasir); B1 (Tandan Kosong Kelapa Sawit); B2 ( Serabut kelapa sawit); B3 (Tandan Kosong + Serabut kelapa sawit); MSI (Minggu Setelah Inkubasi). 
Hal ini disebabkan karena kandungan N-total pada Ultisol lempung berliat sebelum perlakuan lebih tinggi bila dibandingkan dengan Ultisol lempung berpasir.

Nilai rata-rata $\mathrm{N}$-total tanah pada tekstur tanah lempung berliat berkisar antara $0,20 \%-$ $0,23 \%$ dan termasuk dalam kriteria rendah hingga sedang. Namun, nilai tersebut mengalami penurunan $\mathrm{N}$-total tanah sebesar $0,08 \%-0,11 \%$ bila dibandingkan dengan $\mathrm{N}$ total tanah sebelum perlakuan. Sedangkan pada tekstur tanah lempung berpasir memiliki nilai rata-rata $\mathrm{N}$-total sebesar $0,06 \%-0,11 \%$ dengan kriteria sangat rendah hingga rendah. Penurunan kandungan nitrogen dapat terjadi karena $\mathrm{N}\left(\mathrm{NO}_{3}^{-}\right)$yang dihasilkan dari proses mineralisasi bahan organik dikonversi menjadi bentuk nitrit $\left(\mathrm{NO}_{2}\right), \mathrm{N}_{2} \mathrm{O}$ dan $\mathrm{N}_{2}$ oleh mikroba melalui proses denitrifikasi dan pada akhirnya hilang karena penguapan (volatilisasi). Rahman et al. (2013) melaporkan bahwa mineralisasi $\mathrm{N}$ dari bahan organik dan pupuk kandang meningkat sampai dengan 7 minggu inkubasi.

\section{Kadar P-tersedia tanah}

Hasil analisa tanah awal menunjukkan bahwa Ultisol memiliki kandungan P-tersedia sangat rendah yakni sebesar 4,03 ppm (tekstur lempung berliat) dan 2,73 ppm (tekstur lempung berpasir).Hasil penelitian menunjukkan bahwa penambahan bahan organik TKKS selama 12 minggu inkubasi tidak mengubah kriteria P-tersedia tanah yakni masih berada pada kriteria sangat rendah, diduga karena tingginya kandungan $\mathrm{Al}$ di Ultisol yang mampu mengikat $\mathrm{P}$ menjadi bentuk yang tidak tersedia. Pada lokasi pengambilan tanah yang sama, Kurniawan et al. (2018) melaporkan bahwa kejenuhan $\mathrm{Al}$ di lahan kelapa sawit yang tidak memperoleh pengaruh penambahan dolomit lebih dari $60 \%$. Tingginya kejenuhan $\mathrm{Al}$ diduga berpengaruh pada rendahnya $\mathrm{P}$ tersedia dari semua perlakuan penambahan bahan organik residu pengolahan kelapa sawit, dimana $\mathrm{P}$ yang dilepaskan melalui proses mineralisasi diikat oleh Al (Al-P) menjadi bentuk yang tidak tersedia. Namun demikian, pemberian bahan organik dari residu kelapa sawit berpengaruh nyata terhadap P-tersedia tanah pada minggu ke 4 dan 12 setelah inkubasi. Hasil analisis P- tersedia Ultisol akibat penambahan bahan organik TKKS dapat dilihat pada Tabel 1.

Kandungan $\mathrm{P}$ tersedia pada perlakuan TKKS yang lebih tinggi dibandingkan penambahan serabut dan TKKS + serabut (Ultisol lempung berpasir) pada minggu ke-4 setelah inkubasi hampir sama dengan hasil penelitian Tao et al. (2016) yang melaporkan bahwa aplikasi tandan kosong kelapa sawit mampu maningkatkan $\mathrm{P}$ total tanah (Inceptisol) lebih besar dibandingkan dengan aplikasi pangkasan pelepah kelapa sawit. Lebih lanjut, kadar P-tersedia tertinggi ditemukan pada perlakuan T2B1 (Ultisol lempung berpasir + TKKS) di minggu ke-6 setelah masa inkubasi yaitu sebesar 5,97 ppm (meningkat 54\% bila dibandingkan dengan analisa tanah sebelum perlakuan). Sebaliknya, kadar P tersedia pada perlakuan T1B1 (Ultisol lempung berliat + TKKS) turun 30\% dibandingkan kondisi awal sebelum perlakuan (Tabel 1). Hasil tersebut menunjukkan bahwa penambahan bahan organik yang sama (TKKS) memberikan pengaruh yang berbeda pada 2 kelas tekstur tanah.

Pada 12 minggu setelah inkubasi, kadar P tersedia tanah di tanah lempung berpasir pada perlakuan kombinasi TKKS + serabut lebih rendah $(\mathrm{P}<0.05)$ dibandingkan dengan perlakuan tanpa kombinasi (TKKS / serabut; Tabel 1). Hal ini diduga karena TKKS dan serabut memiliki Ca yang lebih besar $(0.87 \%$ dan $0.80 \%$ ) dibandingkan perlakuan TKKS + serabut $(0.46 \%)$, dimana Ca yang dilepaskan melalui mineralisasi akan menggantikan $\mathrm{Al}$ di permukaan kompleks jerapan yang berdampak pada pelepasan $\mathrm{P}$ yang diikat Al. Namun demikian, kondisi ini tidak dijumpai pada tanah lempung berliat dimana $\mathrm{P}$ tersedia tidak berbeda antar perlakuan bahan organik kelapa sawit, diduga karena tanah dengan tekstur berliat mampu mengikat unsur hara lebih kuat tanah-tanah dengan tekstur berpasir.

\section{Kadar K-dd tanah}

Unsur $\mathrm{K}$ ditemukan dalam jumlah banyak di dalam tanah, tetapi hanya sebagian kecil yang digunakan oleh tanaman. Kalium yang tersedia dalam tanah tidak selalu tetap dalam keadaan tersedia, tetapi masih berubah menjadi bentuk yang lambat untuk diserap oleh tanaman. 
Tabel 1. Rerata P-tersedia tanah.

\begin{tabular}{cccccc}
\hline Perlakuan & \multicolumn{5}{c}{ Nilai Rerata Kadar P-tersedia tanah (ppm) \pm s.e.d } \\
\cline { 2 - 6 } & $\mathbf{4}$ MSI & $\mathbf{6}$ MSI & $\mathbf{8}$ MSI & $\mathbf{1 0 ~ M S I}$ & $\mathbf{1 2 ~ M S I}^{*}$ \\
\hline T1B1 & $1,11 \pm 0,77 \mathrm{~b}$ & $2,83 \pm 0,92$ & $1,67 \pm 1,67$ & $1,89 \pm 2,13$ & $1,10 \pm 2,82 \mathrm{a}$ \\
T1B2 & $1,38 \pm 0,26 \mathrm{~b}$ & $3,08 \pm 0,60$ & $0,82 \pm 0,22$ & $1,62 \pm 0,13$ & $1,35 \pm 0,42 \mathrm{ab}$ \\
T1B3 & $0,82 \pm 0,15 \mathrm{ab}$ & $2,75 \pm 0,59$ & $2,45 \pm 1,06$ & $1,62 \pm 0,38$ & $1,61 \pm 0,31 \mathrm{ab}$ \\
T2B1 & $1,29 \pm 0,35 \mathrm{~b}$ & $5,97 \pm 1,67$ & $2,85 \pm 0,59$ & $1,55 \pm 0,30$ & $3,88 \pm 0,92 \mathrm{c}$ \\
T2B2 & $0,26 \pm 0,18 \mathrm{a}$ & $3,91 \pm 1,02$ & $2,58 \pm 0,71$ & $2,59 \pm 0,62$ & $3,37 \pm 0,73 \mathrm{c}$ \\
T2B3 & $0,26 \pm 0,19 \mathrm{a}$ & $3,67 \pm 0,85$ & $1,81 \pm 0,56$ & $2,33 \pm 0,70$ & $2,33 \pm 0,52 \mathrm{~b}$ \\
\hline BNT 5\% & $\mathbf{0 , 3 5}$ & $\mathbf{1 , 2 1}$ & $\mathbf{1 , 0 3}$ & $\mathbf{0 , 5 8}$ & $\mathbf{0 , 4 6}$ \\
\hline
\end{tabular}

Keterangan: Angka rerata yang didampingi huruf yang sama menunjukkan tidak berbeda nyata menurut uji BNT $5 \%$. T1B1 $=$ tanah lempung berliat + TKKS; T1B2 $=$ tanah lempung berliat + serabut; $\mathrm{T} 1 \mathrm{~B} 3=\operatorname{tanah}$ lempung berliat + TKKS + serabut; T2B1 $=$ tanah lempung berpasir + TKKS; T2B2 $=$ tanah lempung berpasir + serabut; T2B3 = tanah lempung berpasir + TKKS + serabut. MSI= Minggu Setelah Inkubasi.

Berdasarkan hasil analisis tanah sebelum perlakuan diketahui bahwa Ultisol memiliki kandungan K-dd sebesar $0,09 \quad \mathrm{cmol} \mathrm{kg}^{-1}$ (Ultisol lempung berliat) dan $0,01 \mathrm{cmol} \mathrm{kg}^{-1}$ (Ultisol lempung berpasir) tergolong dalam kriteria sangat rendah. Secara umum, nilai ratarata K-dd tanah yang diperoleh setelah diinkubasi selama 12 minggu meningkat (berkisar antara 0,05- 0,28 $\mathrm{cmol} \mathrm{kg}^{-1}$ dan tergolong dalam kriteria sangat rendah hingga rendah) akibat adanya pelepasan $\mathrm{K}$ dari proses dekomposisi dan mineralisasi. Namun, hasil yang diperoleh dalam penelitian ini masih lebih rendah dibandingkan dengan penelitian Mulyani (2016) yang menyatakan bahwa penambahan kompos tandan kosong kelapa sawit dan abu boiler pada Ultisol mampu meningkatkan kadar K-dd tanah yakni sebesar $0,50-0,90 \mathrm{cmol} / \mathrm{kg}$. Hasil analisis ragam menunjukkan bahwa aplikasi bahan organik tidak berpengaruh nyata dalam meningkatkan kalium tersedia di dalam tanah setelah diinkubasi selama 12 minggu pada kelas tekstur yang sama. Namun demikian, kadar K-dd pada tanah lempung berliat dari berbagai penambahan bahan organik kelapa sawit lebih tinggi $(\mathrm{P}<0.05)$ dibandingkan dengan $\mathrm{K}$-dd pada tanah lempung berpasir (Gambar 4).

\section{Basa-basa tersedia (Ca-dd, Mg-dd, dan Na-dd Tanah)}

Hasil analisis ragam menunjukkan bahwa aplikasi bahan organik dari residu kelapa sawit (TKKS, serabut, dan TKKS + serabut) pada
Ultisol lempung berliat dan lempung berpasir tidak berpengaruh nyata terhadap kadar Ca-dd, $\mathrm{Mg}$-dd, dan $\mathrm{Na}$-dd, pada periode pengamatan 4, 6, 8, 10, dan 12 minggu setelah inkubasi (Tabel 2). Namun demikian, kandungan Ca-dd dan Mg-dd setelah aplikasi residu kelapa sawit (TKKS, serabut, dan TKKS + serabut) lebih besar dibandingkan dengan kondisi awal sebelum perlakuan $\left(1,43\right.$ dan $0,23 \mathrm{cmol} \mathrm{kg} \mathrm{kg}^{-1}$ untuk lempung berliat, serta 1,53 dan $0,38 \mathrm{cmol}$ $\mathrm{kg}^{-1}$ untuk lempung berpasir). erbeda dengan Ca-dd dan Mg-dd, kandungan Na-dd setelah aplikasi residu kelapa sawit (TKKS, serabut, dan TKKS + serabut) tidak mengalami perubahan yang signifikan baik pada Ultisol lempung berliat maupun lempung berpasir (Tabel 2).

Peningkatan kandungan $\mathrm{Ca}$-dd dan $\mathrm{Mg}$ dd tanah terjadi karena adanya sumbangan $\mathrm{Ca}$ dan $\mathrm{Mg}$ yang berasal dari bahan organik tandan kosong dan serabut kelapa sawit. Kandungan Ca pada tandan kosong dan serabut kelapa sawit sebesar $0,87 \%$ dan $0,80 \%$ sedangkan kandungan $\mathrm{Mg}$ pada tandan kosong dan serabut kelapa sawit berturut-turut sebesar $0,09 \%$ dan $0,20 \%$. Hal ini sesuai dengan Mulyani (2016) yang menyatakan bahwa aplikasi kompos tandan kosong kelapa sawit dan abu boiler mampu meningkatkan kadar Cadd pada Ultisol sebesar 41,28\% dibandingkan dengan tanah tanpa pemberian kompos dan mampu meningkatkan kadar Mg-dd Ultisol sebesar 1,24 - 1,42 $\mathrm{cmol} \mathrm{kg}^{-1}$. 


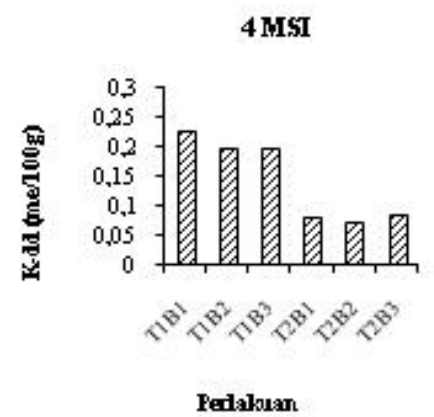

(a)

10 MSI

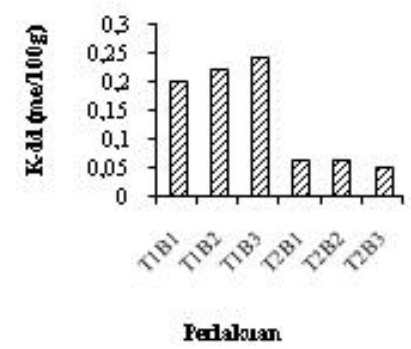

(d)
6 MST

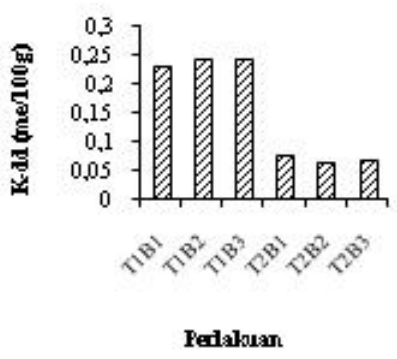

(b)

12 MSI

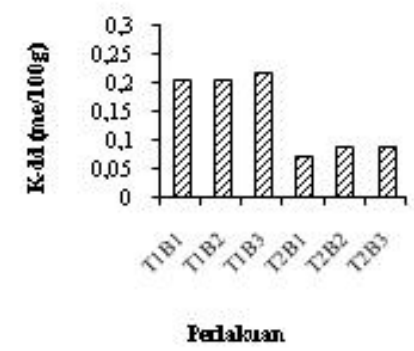

(e)
8 MST

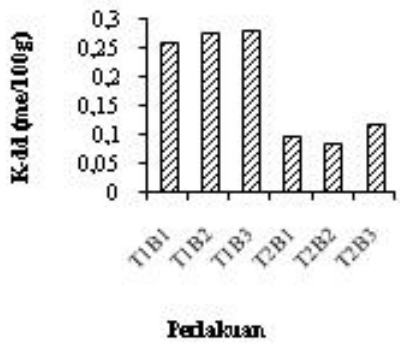

(c)

Gambar 4.Pengaruh perlakuan penambahan tandan kosong kelapa sawit terhadap K-dd tanah pada waktu pengamatan 4 MSI (a), 6 MSI (b), 8 MSI (c), 10 MSI (d), dan 12 MSI (e).

Keterangan:T1 (Tekstur tanah lempung berliat); T2 (Tekstur tanah lempung berpasir); B1 (Tandan Kosong Kelapa Sawit); B2 ( Serabut kelapa sawit); B3 (Tandan Kosong + Serabut kelapa sawit); MSI (Minggu Setelah Inkubasi).

\section{Kapasitas tukar kation (KTK) tanah}

Ultisol lempung berliat yang digunakan dalam penelitian ini memiliki KTK yang lebih besar $\left(25,93 \mathrm{cmol} \mathrm{kg}^{-1}\right)$ dibandingkan dengan Ultisol lempung berpasir( $\left.14,73 \mathrm{cmol} \mathrm{kg}^{-1}\right)$. Hal ini diduga karena pengaruh dari liat dimana tanah dengan kandungan liat yang lebih tinggi cenderung memiliki KTK yang lebih besar dibandingkan dengan tanah berpasir. Partikel liat tinggi memiliki nilai KTK yang lebih tinggi, karena memiliki luas permukaan luar yg lebih tinggi dibanding partikel pasir atau debu. Hasilyang diperoleh sesuai dengan penelitian Silver et al. (2000) dan Allen et al. (2016) yang menjelaskan bahwa kapasitas tukar kation meningkat pada tanah-tanah yang memiliki kandungan liat lebih tinggi. Hal ini disebabkan karena liat memiliki muatan permukaan negatif dan luas permukaan yang lebih besar sehingga mampu mengikat dan mempertukarkan kationkation yang lebih banyak dibandingkan dengan fraksi pasir / debu. Faktor lain yang mempengaruhi KTK tanah adalah kandungan bahan organik tanah / humus. Berdasarkan hasil analisis ragam, pemberian bahan organik TKKS berpengaruh nyata terhadap KTK tanah. Penambahan bahan organik yang berasal dari residu kelapa sawit mampu meningkatkan nilai KTK tanah bila dibandingkan dengan analisa sebelum perlakuan (Gambar 5). Secara keseluruhan, rata-rata nilai KTK tanah pada kedua jenis tekstur tanah selama inkubasi berkisar antara 14,11 $\mathrm{cmol} \mathrm{kg}^{-1}$ (rendah) hingga 41,41 $\mathrm{cmol} \mathrm{kg}^{-1}$ (tinggi). Pada Ultisol lempung berliat, peningkatan KTK tanah tertinggi terjadi pada minggu ke 8 setelah inkubasi yakni pada perlakuan T1B1 (perlakuan tandan kosong kelapa sawit / TKKS), yaitu sebesar 41,41 cmol $\mathrm{kg}^{-1}$. 
Tabel 2. Rerata kation-kation basa Ca-dd, Mg-dd, dan Na-dd

\begin{tabular}{|c|c|c|c|c|c|c|}
\hline \multirow{2}{*}{$\begin{array}{c}\text { Kation } \\
\text { basa }\end{array}$} & \multirow{2}{*}{ Perlakuan } & \multicolumn{5}{|c|}{ Nilai rerata \pm s.e.d $\left(\mathrm{cmol} \mathrm{kg}^{-1}\right)$} \\
\hline & & 4 MSI & 6 MSI & 8 MSI & $10 \mathrm{MSI}$ & 12 MSI \\
\hline \multirow{6}{*}{$\mathrm{Ca}$} & T1B1 & $2,91 \pm 0,34$ & $2,28 \pm 1,00$ & $2,43 \pm 1,49$ & $1,38 \pm 2,23$ & $1,90 \pm 2,62$ \\
\hline & T1B2 & $1,73 \pm 0,74$ & $3,00 \pm 0,89$ & $1,88 \pm 0,16$ & $1,92 \pm 0,22$ & $2,20 \pm 0,24$ \\
\hline & T1B3 & $3,21 \pm 0,89$ & $2,39 \pm 0,41$ & $1,81 \pm 0,47$ & $2,01 \pm 0,49$ & $2,32 \pm 0,61$ \\
\hline & T2B1 & $2,54 \pm 0,47$ & $1,53 \pm 0,31$ & $1,78 \pm 0,38$ & $1,78 \pm 0,38$ & $1,63 \pm 0,32$ \\
\hline & T2B2 & $3,05 \pm 0,67$ & $1,90 \pm 0,47$ & $1,68 \pm 0,35$ & $1,73 \pm 0,37$ & $1,48 \pm 0,32$ \\
\hline & $\mathrm{T} 2 \mathrm{~B} 3$ & $2,30 \pm 0,42$ & $1,39 \pm 0,24$ & $1,88 \pm 0,47$ & $1,78 \pm 0,41$ & $1,73 \pm 0,39$ \\
\hline \multicolumn{2}{|c|}{ BNT 5\% } & 0,79 & 0,70 & 0,47 & 0,36 & 0,41 \\
\hline \multirow{6}{*}{$\mathrm{Mg}$} & T1B1 & $1,59 \pm 0,70$ & $1,35 \pm 1,40$ & $0,59 \pm 1,92$ & $1,22 \pm 2,28$ & $1,21 \pm 2,83$ \\
\hline & T1B2 & $1,02 \pm 0,28$ & $0,95 \pm 0,35$ & $1,44 \pm 0,47$ & $1,28 \pm 0,32$ & $1,72 \pm 0,39$ \\
\hline & T1B3 & $1,17 \pm 0,54$ & $1,03 \pm 0,53$ & $1,81 \pm 0,50$ & $0,85 \pm 0,21$ & $1,38 \pm 0,65$ \\
\hline & T2B1 & $1,73 \pm 0,43$ & $0,61 \pm 0,17$ & $0,56 \pm 0,15$ & $1,22 \pm 0,28$ & $1,88 \pm 0,44$ \\
\hline & T2B2 & $0,94 \pm 0,27$ & $0,26 \pm 0,04$ & $2,29 \pm 1,22$ & $0,92 \pm 0,28$ & $1,69 \pm 0,50$ \\
\hline & T2B3 & $1,43 \pm 0,39$ & $0,77 \pm 0,39$ & $1,47 \pm 0,47$ & $1,69 \pm 0,43$ & $0,61 \pm 0,33$ \\
\hline \multicolumn{2}{|c|}{ BNT 5\% } & 0,66 & 0,85 & 1,12 & 0,42 & 0,83 \\
\hline \multirow{6}{*}{$\mathrm{Na}$} & T1B1 & $0,32 \pm 0,95$ & $0,22 \pm 1,49$ & $0,31 \pm 1,99$ & $0,28 \pm 2,51$ & $0,18 \pm 3,05$ \\
\hline & $\mathrm{T} 1 \mathrm{~B} 2$ & $0,30 \pm 0,17$ & $0,24 \pm 0,33$ & $0,34 \pm 0,43$ & $0,28 \pm 0,58$ & $0,19 \pm 0,74$ \\
\hline & T1B3 & $0,30 \pm 0,05$ & $0,25 \pm 0,02$ & $0,34 \pm 0,04$ & $0,32 \pm 0,07$ & $0,20 \pm 0,14$ \\
\hline & $\mathrm{T} 2 \mathrm{~B} 1$ & $0,24 \pm 0,06$ & $0,25 \pm 0,07$ & $0,30 \pm 0,07$ & $0,26 \pm 0,05$ & $0,16 \pm 0,02$ \\
\hline & T2B2 & $0,29 \pm 0,06$ & $0,20 \pm 0,04$ & $0,30 \pm 0,06$ & $0,28 \pm 0,06$ & $0,18 \pm 0,05$ \\
\hline & T2B3 & $0,29 \pm 0,06$ & $0,20 \pm 0,04$ & $0,32 \pm 0,07$ & $0,29 \pm 0,06$ & $0,19 \pm 0,04$ \\
\hline \multicolumn{2}{|c|}{ BNT 5\% } & 0,05 & 0,04 & 0,06 & 0,05 & 0,04 \\
\hline
\end{tabular}

Keterangan: Angka rerata yang didampingi huruf yang sama menunjukkan tidak berbeda nyata menurut uji BNT 5\%. T1B1 = tanah lempung berliat + TKKS; T1B2 = tanah lempung berliat + serabut; T1B3 = tanah lempung berliat + TKKS + serabut; T2B1 = tanah lempung berpasir + TKKS; T2B2 = tanah lempung berpasir + serabut; T2B3 = tanah lempung berpasir + TKKS + serabut. MSI $=$ Minggu Setelah Inkubasi.

Hasil yang sama juga terjadi pada Ultisol lempung berpasir, dimana nilai KTK tertinggi (8 MSI) terdapat pada perlakuan TKKS (T2B1), yaitu sebesar 24,34 $\mathrm{cmol} \mathrm{kg}^{-1}$. Hasil uji korelasi menunjukkan bahwa C-organik tanah dan kapasitas tukar kation (KTK) memiliki hubungan yang positif dan kuat $(\mathrm{r}=0,99 ; \mathrm{r}$ tabel $=0,58)$, memperkuat berbagai penelitian yang telah dilakukan sebelumnya bahwa KTK tanah dipengaruhi oleh kandungan bahan organik tanah. Besarnya nilai KTK pada waktu inkubasi 8 minggu terjadi karena bahan organik tandan kosong kelapa sawit dan serabut mengalami proses dekomposisi sehingga menghasilkan banyak koloid bermuatan negatif. Liang et al. (2006) menjelaskan bahwa peningkatan KTK terkait dengan bahan organik melalui dua mekanisme yaitu: 1) peningkatan kerapatan muatan per unit luas permukaan yang diartikan sebagai peningkatan derajat/laju oksidasi bahan organik, dan 2) peningkatan luas permukaan untuk jerapan kation, atau kombinasi keduanya.

\section{Kesimpulan}

Pemberian residu padat kelapa sawit pada Ultisol bertekstur lempung berliat dan lempung berpasir berpengaruh nyata terhadap Corganik, N-total, K-dd, dan KTK tanah sehingga mampu meningkatkan ketersediaan hara pada Ultisol. Aplikasi limbah tandan kosong dan serabut kelapa sawit pada tanah lempung berliat (T1B3) meningkatkan Corganik, K-dd, dan KTK tanah secara signifikan pada pengamatan $12 \mathrm{MSI}$, masingmasing sebesar $400 \%, \quad 150 \%$, dan $17 \%$ dibandingkan dengan kondisi awal sebelum penelitian. Hasil penelitian menunjukkan bahwa residu kelapa sawit (tandan kosong) berpotensi sebagai salah satu sumber pupuk organik pada lahan kelapa sawit dan dapat diaplikasikan melalui kombinasi atau tanpa kombinasi dengan pupuk kandang dalam upaya meningkatkan kesuburan tanah Ultisol sekaligus mengurangi biaya penggunaan pupuk kimia 
4MSI

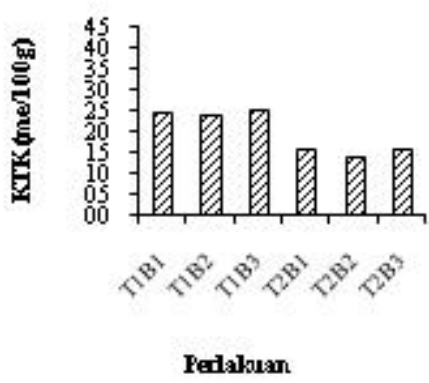

(a)

10 MSI

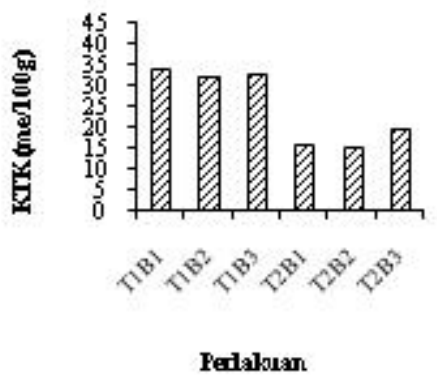

(d)
6 MST

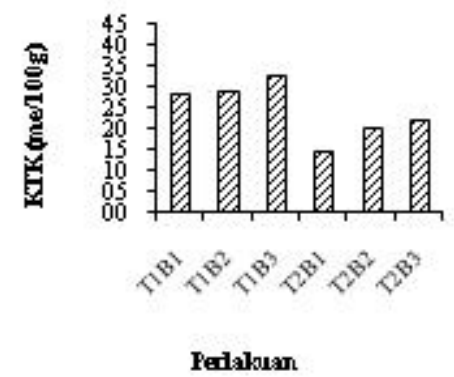

(b)

12 MSI

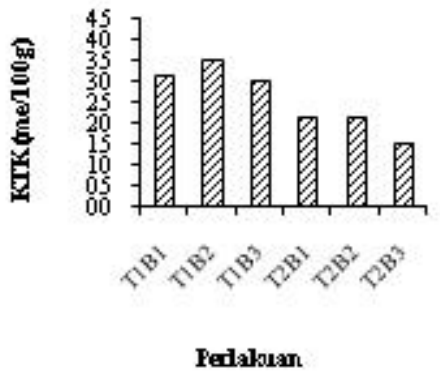

(e)
8 MST

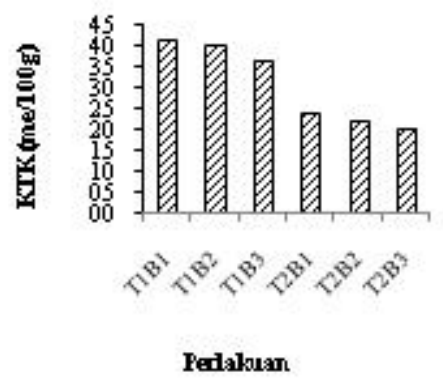

(c)

\begin{abstract}
Gambar 5.Pengaruh perlakuan penambahan tandan kosong kelapa sawit terhadap KTK tanah pada waktu pengamatan 4 MSI (a), 6 MSI (b), 8 MSI (c), 10 MSI (d), dan 12 MSI (e).

Keterangan:T1 (Tekstur tanah lempung berliat); T2 (Tekstur tanah lempung berpasir); B1 (Tandan Kosong Kelapa Sawit); B2 ( Serabut kelapa sawit); B3 (Tandan Kosong + Serabut kelapa sawit); MSI (Minggu Setelah Inkubasi).
\end{abstract}

\section{Ucapan Terima Kasih}

Penelitian ini merupakan bagian dari kegiatan penelitian "Nutrient release from decomposition of oil palm fruit bunches" yang didanai oleh DFG Germany dalam kegiatan Collaborative Research Centre (CRC990) Ecological and Socio-economic functions of tropical lowland rainforest transformation systems, Sumatra - Indonesia (EFFORTs) melalui skema pendanaan Access Benefit Sharing (ABS) tahun 2017.

\section{Daftar Pustaka}

Allen, K.A., Corre, M.D., Tjoa, A. and Veldkamp, E. 2015. Soil nitrogen-cycling responses to conversion of lowland forests to oil palm and rubber plantations in Sumatra, Indonesia. PLoS ONE 10 (7): 1-21.
Allen, K.A., Corre, M.D., Kurniawan, S., Utami, S.R. and Veldkamp, E. 2016. Spatial variability surpasses land-use change effects on soil biochemical properties of converted lowland landscapes in Sumatra, Indonesia. Geoderma, 284: 42-50.

Bakar, R. A., Darus, S. Z., Kulaseharan, S. and Jamaluddin, N. 2011. Effects of ten year application of empty fruit bunches in an oil palm plantation on soil chemical properties. Nutrient Cycling in Agroecosystems 89, 341349.

Darmosarkoro dan Winarna. 2001. Penggunaan Tandan Kelapa Sawit dan Kompos Tandan Kelapa Sawit Untuk Meningkatkan Pertumbuhan dan Produksi Tanaman. Prosiding: Lahan dan Pemupukan Kelapa Sawit (ed, Witjaksana, D., Edy. S. S., dan Winarna) 
Pusat Penelitian Kelapa Sawit, Medan, Desember 2003. pp 187-200.

Departemen Pertanian. 2006. Pedoman Pengelolaan Limbah Industri Kelapa Sawit. Subdit Pengelolaan, Dit. Pengelolaan Hasil Pertanian, Ditjen PPHP, Departemen Pertanian Jakarta.

Direktorat Jenderal Perkebunan. 2016. Statistik Perkebunan Indonesia: Tree Crop Estate Statistic of Indonesia. Kementerian Pertanian. Jakarta.

Eliarti. 2013. Perbaikan Kualitas Kompos Tandan Kosong Kelapa Sawit dengan Penambahan Abu Boiler serta Pengaruhnya terhadap Sifat Kimia Podsolik Merah Kuning dan Tanaman Caisim (Brassica juncea). M.S. Thesis. Institut Pertanian Bogor.

Kurniawan, S., Corre, M.D., Utami, S.R. and Velkamp, E. 2018. Soil biochemical properties and nutrient leaching from smallholder oil palm plantations, Sumatra - Indonesia. Agrivita 40 (2): 257-266.

Liang, B., Lehmann, J., Solomon, D., Kinyangi, J., Grossman, J., O’Neill, B., Skjemstad, J.O., Thies, J., Luizao, F.J., Petersen, J., and Neves, E.G. 2006. Black carbon increases cation capacity in soils. Soil science Society of America Journal70 (5) : 1719-1730.

Manambangtua dan Barri. 2016. Pemanfaatan Tandan Kosong (Tankos) Limbah Kelapa Sawit sebagai Pupuk Organik. Warta Penelitian dan Pengembangan Tanaman Industri 22 (1): 18-20.
Mulyani, S. 2016. Peningkatan Kualitas Kompos Tandan Kosong Kelapa Sawit Dengan Abu Boiler dan Pengaruhnya Terhadap Sifat Kimia Ultisol serta Tanaman Sawi. M.S. Thesis. Institut Pertanian Bogor.

Prasetyo, B. dan Suriadikarta, H. 2006. Karakteristik, Potensi dan Teknologi Pengelolaan Ultisol untuk Pengembangan Pertanian Lahan Kering di Indonesia. Jurnal Litbang Pertanian 25 (2), 1-9.

Rahman, M.H., Islam, M.R., Jahiruddin, M., Puteh, A.B., and Mondal, M.M.A. 2013. Influence of organic matter on nitrogen mineralization pattern in soils under different moisture regimes. International journal of Agriculture and Biology 15: 55-61

Silver, W.L., Neff, J., McGroddy, M., Veldkamp, E., Keller, M. and Cosme, R., 2000. Effects of soil texture on belowground carbon and nutrient storage in a lowland Amazonian Forest ecosystem. Ecosystems 3: 193 - 209.

Tao, H. H., Slade, E. M., Willis, K. J., Caliman, J. P. and Snaddon, J.L. 2016. Effect of soil management practices on soil fauna feeding activity in an Indonesian oil palm plantation. Agriculture, Ecosystems, and Environment 218: 133-140. 